\title{
Social Motivation for the Emergence \\ of New Terms in Modern Chinese Language
}

\author{
Hongzhi Wu \\ Qingdao University of Science and Technology \\ Qingdao 266061, China \\ E-mail: yx_jinxiuwhz@126.com
}

\begin{abstract}
This paper attempts to discuss social motivation for the emergence of new terms in modern Chinese language from six perspectives. They are social development, foreign influence, social stratification, the change of values, the organic whole of media and the growth of specialized knowledge as well as people's life style, and “酷一族”. Linguistic motivation is also discussed briefly as the complementary reason for this language phenomenon.
\end{abstract}

Keywords: Social motivation, Modern Chinese, Emergence, Linguistic motivation

\section{Introduction}

Language is characterized by change and Eugene A. Nida (2001:81) says, "Since all languages are open systems, they have the potentiality for growth, change, and decline." The change manifests itself in sound, grammar and semantics, but the most salient one is semantic change. According to David Crystal (2002:332), semantic change is the most obvious area of linguistic change, and the one which many people find the most fascinating.

However, even semantic change is too complicated since it is profoundly connected with the life, literature and culture of one community (Crystal, 2002:332). Considering the feasibility, the author will only concentrate on one aspect of semantic change - the emergence of new terms (新词语) in modern Chinese language, especially in the new period.

The new period refers to the past period since the end of 1970's when the policy of reform and opening-up was adopted. According to Ou Yangyin (2000:3), there appeared more than 3,000 new terms in Chinese language since the end of 1970's.

Why do new terms (新词语) emerge?

With respect to the reasons for language change, Jean Atchison (1997:3) holds that language changes are an interwoven mix of social triggers, structural factors and psychological processes. David Crystal (2002:335) also has the similar view that there is no single reason for language change. Several factors turn out to be implicated, some to do with the nature of language structure, and some with the nature of society.

To sum up, two factors play an important role in language change - linguistic motivation and social motivation. As one aspect of language change, the question of the emergence of new terms in Chinese language, though language - specific, will be discussed from the same perspective.

\section{Linguistic motivation for the emergence of new terms in Chinese Language}

Language is self -- organized and language is likely to change and evolve from the state of disorder to the state of order (Wang Ailu, 2002:1; Shu Dingfang, 2002:60). This feature guarantees that the motivation for language should be analyzed linguistically. In other words, linguistic motivation firstly means that the reason for language change can only be explained within language itself. For example, an obsolete word is replaced by a new word just because the new word is easier in pronunciation and spelling. In this sense, Jean Atchison (2002:157) claims that language can easily build and rebuild itself out of its existing resources. On the other hand, linguistic motivation also means that it gives the internal impetus for language change.

Take Chinese for instance. Chinese new words can be created by the combination of two familiar words (A new word $=$ word $_{1}+$ word $_{2}$ ). Examples are 电脑 $=$ 电 + 脑, 学历教育 $=$ 学历+教育 and 骗汇=骗 + 汇 etc. This rule must be 
strictly observed when new terms are produced in this pattern. Any attempts against the rule will be futile. For example, expressions like 最最 or 最小最小最小 appeared in Cultural Revolution in China, but soon they passed into history.

Specifically speaking, there are different aspects of linguistic motivation.

1. The principle of economy. Economy is also called "the use of minimum effort" (Florian Coulmas, 2001:84), which means words or sentences tend to be simplified for the sake of economy. For instance, 在德智体三方面表现都好的学 生 can be shortened as 三好学生 and 打击拐卖妇女儿童 as 打拐. The most influential example is the simplification of Chinese characters.

2. The principle of incompleteness of language. Language tends to change and grow from incompleteness to completeness. One method is that a language takes in some foreign words or expressions. The absorption can help a language to be complete and accurate. A case in point is that Chinese language takes in many foreign words like 飞机, 蜜月，马力，激光，科学，民主，克隆，比基尼，艾滋病，丁克家族.

Linguistic motivation is far more complicated than mentioned above. What concerns us is that linguistic motivation is not only one factor involved in formation of new words but also serves as the internal drive winch helps social factors give full play in this process.

\section{Social motivation}

\section{1 language and society}

We are ignorant of language origin, but we do know that language appeared later than human society. Thus from the diachronic perspective, we may safely conclude that language is closely related to society since the date of its birth.

The interrelationship between language and society has always been focused and the research in this regard helps the birth of sociolinguistics. Though unable to provide clear-cut answers to such a challenging question which can be traced back to 2,000 years ago, the development in sociolinguistics has proved that some social factors influence our language behavior in a social context and some major ones are class, gender, age, ethnic identity, occupation and religious belief (Hu Zhanglin, 2002).

Since language can never function independently if there are no social contexts to fit it in (Alptekin, 1993 in Hu Zhuanglin, 2002), Robins explains that:

The condition of life of individuals in society, their artifacts, customs, forms of organization, forms of organization, and the like are constantly changing; and consequently the referents of many words in languages and the situations in which they are employed are equally liable to change in the course of time. New products often require new designations, and some words pass out of current vocabulary as the particular sorts of objects or ways of behaving to which they refer become obsolete (2000:343).

What Robins means is that with the intervention of social factors, language, particularly words, are motivated to change: old words are obsolete and new terms emerge. Now we are clear that social motivation is the main reason for emergence of new terms.

\subsection{Social factors in emergence of new terms in Chinese language}

Generally speaking, new terms (新词语) often emerge at the era of great historic change. In Chinese history, several periods are characterized by the phenomenon. In Northern and Southern Dynasties (386-589), many loan words of religion entered ancient Chinese language with the wide spreading of Buddhism (Liu Hongmo, 2000). In modern era, a lot of new terms emerged, especially since the 1970's when China adopted the reform and opening - up policy (Chen Zhangtai, 2002).

Reviewing history of emergence of new terms, we know that the question of social motivation for this language phenomenon should be considered in the context of social changes.

1) The first important factor of great importance to the emerging of new terms is the social development. With the social development, new objects and ideas are continually being created and they require new vocabulary to take account of them. Referential function of language plays its role in this regard. In other words, "the use of language to record facts is a prerequisite of social development" (Hu Zhuanglin, 2002:22).

Since the founding of new China in 1949, there have been great changes in politics, economics, culture, value system etc. Accordingly, new things have appeared one after another and they need new words to express them. In politics, there are 土改, 三反五反, 反右, 文革，四化，公务员，合同制干部，一国两制，后门工程 etc. In economics，we may find 经济过热, 市场潜量, 台商, 入世, 拓销, 银行呆帐, B 股 etc. In science and technology, there appeared 火炬计划, 机器人, 克隆,太空人, 硬件, 电子书 etc.

Such terms account for a large proportion of new words appeared in the past several decades and it is true that the development of new words to meet new social conditions is one of the most familiar phenomena of our language 
(Baugh, A. C. et al, 2002:2).

2) With the increase of cross - cultural communication and globalization, Chinese vocabulary enriches itself by borrowing words from other languages.

In modern times, China has been opening to the outside world and the contact between Chinese language - culture and other language - culture is being enhanced. As a result, many borrowed words entered Chinese vocabulary. Directing at language phenomenon like this, Baugh (2002:196) comments that the exchange of commodities and the exchange of ideas are both stimulating to language. For instance, English language - culture exerts a great influence on Chinese language - culture and therefore Chinese absorbs many English words such as 雷达, 苏打, 咖啡, 沙发, 尼古丁, 威 士忌, 可口可乐, 香波, 蓝领, 智商, 二手商品 etc.

On the other hand, even within Chinese language - culture itself, the communication between different subcultures also brings in some new entries to Chinese language. Such examples are 砍价 from Beijing dialect and 打工仔, 发烧友, 大哥大, 大排挡, 买单, 泊车 which are all from Cantonese.

It seems that the trend of borrowing terms from other languages is irreversible. As long as Chinese speakers contact other language — culture, they will borrow some terms willingly or unwillingly.

3) The stratification of society contributes to the formation of new terms.

The relationship between social class and language is rather controversial and even the classical research by Bernstein or by Labov is being criticized and challenged (Zhu Wanjin, 1992:91-106; Fasold, 2000:223-226). However, it is a fact that the way people talk has something to do with their social position or level of education (David Crystal, 2002:38). In China there are 10 social strata that can be regrouped to 5 groups based on their economic status and therefore new social group dialects are in the cradle (Chen Zhangtai, 2002).

Perhaps one should be careful in make the judgment, but many newly_-formed terms are characterized by social group dialects. There are 研究研究, 考虑考虑, 好好想想 in officialdom, 话语, 解构, 文本, 颠覆 in art and literary circles, 充电, 科研型教师, 高职低聘, 岗位津贴, 继续教育 in education. More importantly, many new terms are closely related to different social groups. In entertainment, there are 影星, 做秀, 走穴 etc. In business, there are 贺岁 片, 总裁, 总经理, 公关小姐, 首代 etc.

It is predicted that with the development of social stratification more new terms will appear in the future.

4) The change of values yields emergence of some new terms.

Language and culture are symbiotic. Language is used by culture to perform its function, such as providing information about the processes and the values of a culture (Nida, 2001:152). Specifically speaking, with changing of value systems, the vocabulary will also experience corresponding alterations (such as emergence of new terms) to meet new situations.

In Chinese, derogatory words like 戏子, 垃圾工, 差生, 异类, 同性恋, 二奶, 聋哑学校 etc. are replaced by neutral terms 演员, 保洁员, 潜能生, 新新人类, 同志, 红颜知己, 特殊学校 respectively. Such replacement reflects that people are reconsidering their stereotyped values and they are more tolerant of these social phenomenon.

However, it is noticed that the change is bi-directional. Apart from appreciative or neutral words such as 男士, 老公, 家庭主男, 试婚, some dirty words or jargons like 泡妞, 扎蜜 etc. also appeared.

5) Media, the growth of specialized knowledge in different lines of businesses and people's living style - the organic whole of three is the impetus to the formation of new terms.

Language interacts with human beings and the functional view holds that language changes with the change of language users' needs (Jean Aitchison, 1997:152). Therefore, we cannot only rely on the slow course of natural linguistic evolution; sometimes, people's intervention to language is necessary, such as language planning (David Crystal, 2002:365). As far as vocabulary is concerned, new words will be created, diffused and accepted.

Since much of human activities are involved in various kinds of trades or professions, new terms related to these areas will be created. With the help of media, the new terms spread and are finally accepted by the people whose life style is profoundly influenced by media as well as different kinds of lines of businesses. In this sense, it is held that three factors, namely, media, line of business and people's life style together help to bring about new terms related to specialized knowledge in different trades or professions.

In economics and business, there are 经济效益, 劳务市场, 下海, 外引内联, 入关, 利改税, 个体户, 紧俏, 出血价, 套汇, 二手股, 强势 etc.

In science and technology, there are 信息科学, 火炬计划, 机器人, 金卡工程, 克隆, 太空船, 硬科学, 滑坡, 奔腾, 全息码, 电子杂志, 网吧 etc.

In education, there are 教德, 教质, 双学士, 亲子教育, 无墙大学, 陪读, 211 工程, 情商教育, 流师, 助学贷款 etc. 
In medicine, there are 代孕, 血液银行, 基因诊断, 亚健康, 节日病, 颜色疗法, 健身, 减肥 etc.

In military field, there are 核扩散, 军转民, 空战, 拥军, 全天候 etc.

Evidently these words appeared with the increased public interests in various kinds of human activities. On the other hand, the improvements in the mode of living and the infiltration of media contribute to the increase of new words.

6) Apart from the five aspects mentioned above, social factors like social prestige, bilingual education, the quickening of pace of life and "酷一族" also play an important role. For instance, people nowadays tend to use simplified terms for the sake of economy and efficiency. They use “市售” instead of “市场出售” and “离女” instead of “离了婚的女性”.

Another social factor is the social group called “酷一族” (Chen Zhangtai, 2002). Generally speaking, they are young people with different background and occupation, but they seek both change and conformity. The seeking of change means they tend to use new words to show that they are different. The seeking of conformity means that they use new terms to indicate that they belong to the group called “新新人类” or something.

It is impossible and unnecessary to list all social factors that motivate the emergence of new terms in modern Chinese language, but we have noticed that social forces are the primary drive in this regard.

\section{Conclusion}

The article is an attempt to combine general linguistic theory with the practical use of modern Chinese language. In other words, some phenomena in Chinese language are observed from wider perspective: putting language - specific phenomenon under the test of language - general theory. After the small — scale research, it has been found that general linguistic theory can perfectly explain some language - specific phenomena which in turn can confirm the former. Specifically speaking, the emergence of new terms in modern Chinese language is due to two factors-linguistic motivation and social motivation. However, the linguistic motivation plays a more important role. Baugh (2001:295) also comments that when the object, experience, observation or something has entered public consciousness a new word enters the language. Based on his conclusion, we can safely make a judgment that social force is the mother of a new term.

\section{References}

Aitchison, J. (1997). Language Change: Progress or Decay. Beijing: Chinese Language Press (Yuwen Chubanshe).

Baugh, A. C. et al. (2002). A History of the English Language Forth Edition. Beijing: Foreign Language Teaching and Research Press.

Chen, Zhangtai. (2002). On the Language Variations in the New Period. Language Teaching and Research, No. 6.

Coulmas, F. (ed). (2002). The Handbook of Sociolinguistics. Beijing: Foreign Language Teaching and Research Press.

Crystal, D. (2002). The Cambridge Encyclopedia of Language Second Edition. Beijing: Foreign Language Teaching and Research Press.

Eugene A. Nida. (2001). Language and Culture: Contexts in Translating. Shanghai: Foreign Language Education Press.

Fasold, R. (2000). The Sociolinguistics of Language. Beijing: Foreign Language Teaching and Research Press.

Hu, Zhuanglin. (2002). Linguistics: An Advanced Course Book. Beijing: Beijing University Press.

Liu, Hongmo. (2002). Fashionable Words. Guangzhou: Guangdong Tourism Publishing House (Guangdong Lvyou Chubanshe)

Ou, Yangyin. (1997). Longman Dictionary of Chinese Popular New Terms. Beijing: Renmin University of China.

Shu, Dingfang. (2000). An Introduction to Contemporary Linguistic Semantics. Shanghai: Foreign Language Education Press.

Wang, Ailu. (2002). Study on Linguistic Motivations. Beijing: China Social Sciences Press.

Zhu, Wanjin. (1992). Sociolinguistics: An Introduction. Changsha: Hunan Education Press. 